\title{
Effect of the Holding Temperature and Vacuum Pressure for the Open Cell Mg Alloy Foams
}

\author{
Xue-Zheng Yue and Bo-Young Hur ${ }^{\dagger}$ \\ i-Cube Group, ERI, School of Nano and Advanced Material Engineering, Gyeongsang National University, \\ 501, Jinju-daero, Jinju, Gyeongnam, Korea
}

(Received May 31, 2012 : Received in revised form June 13, 2012 : Accepted June 13, 2012)

\begin{abstract}
Metal foam has many excellent properties, such as light weight, incombustibility, good thermal insulation, sound absorption, energy absorption, and environmental friendliness. It has two types of macrostructure, a closed-cell foam with sealed pores and an open-cell foam with open pores. The open-cell foam has a complex macrostructure consisting of an interconnected network. It can be exploited as a degradable biomaterial and a heat exchanger material. In this paper, open cell Mg alloy foams have been produced by infiltrating molten $\mathrm{Mg}$ alloy into porous pre-forms, where granules facilitate porous material. The granules have suitable strength and excellent thermal stability. They are also inexpensive and easily move out from open-cell foamed Mg-Al alloy materials. When the melt casting process used an inert gas, the molten magnesium igniting is resolved easily. The effects of the preheating temperature of the filler particle mould, negative pressure, and granule size on the fluidity of the open cell $\mathrm{Mg}$ alloy foam were investigated. With the increased infiltration pressure, preheat temperature and granule sizes during casting process, the molten AZ31 alloy was high fluidity. The optimum casting temperature, preheating temperature of the filler particle mould, and negative pressure were $750^{\circ} \mathrm{C}, 400-500^{\circ} \mathrm{C}$, and $5000-6000 \mathrm{~Pa}$, respectively, At these conditions the AZ31 alloy had good fluidity and castability with the longest infiltration length, fewer defects, and a uniform pore structure.
\end{abstract}

Key words Mg alloy, infiltration, open cell, metal foam.

\section{Introduction}

Open cell Metallic foams is a kind of novel porous material, which can be fabricated by many methods. ${ }^{1)}$ There currently exist a wide range of manufacturing methods, ${ }^{2)}$ which can generally be grouped into four categories. They are (1) casting method; (2) powder metallurgy; (3) chemical or physical deposition of metal on plastic foams; (4) releasing gas into a melt prior to solidification. ${ }^{3-6)}$ Open cell Metallic foams have found increasing application as catalyst supports, ${ }^{7)}$ filters for high-velocity flow, ${ }^{8)}$ viscous media, ${ }^{9)}$ heat exchangers, $\left.{ }^{10}\right)$ volumetric flow-through electrodes ${ }^{11)}$ and porous burners. ${ }^{12)}$ Remarkable progress in commercial application of opencell foams has been achieved owing to their unique cellular structure which ensures high hydraulic permeability, high surface-to-volume ratio and various choice of possible compositions. This has resulted in an increased number of publications related to foam simulation models and algorithms for the evaluation and prediction of the foams' hydraulic, heat transfer and mass transfer properties which depend on the foam structural parameters. ${ }^{13-14)}$

A. R. Kennedy ${ }^{15)}$ considered, open cell $\mathrm{Al}$ alloy foam

${ }^{\dagger}$ Corresponding author

E-Mail : hurby@gnu.ac.kr (B. Y. Hur) made by infiltration process. He analyzed experimental observations and a infiltration model. Carnelli $\mathrm{D}^{16)}$ studied on open cell $\mathrm{Cu}$ alloy and DP steel by molten infiltration process about Mechanical properties of opencell, self-expandable shape memory alloy carotid stents. P. Fernande $z^{17)}$ considered surface area estimation for open cell $\mathrm{Al}$ alloy by molten infiltration process, he described the mechanical properties of open-cell aluminum alloy foams associated with metallographic phases, size and morphology cells. N. Q. Zhao ${ }^{18)}$ investigated the effect of $\mathrm{Y}_{2} \mathrm{O}_{3}$ on the mechanical properties of open cell aluminum foams. Magnesium alloy has been widely applied in various fields as one of the lightest structure materials because of its good performances. ${ }^{19)}$ AZ31 is a wrought magnesium alloy that is widely applied for its excellent deforming property and satisfactory comprehensive property. The open cell $\mathrm{Mg}$ alloy foam as the lightest advanced metal material will attract more and more attention. However, the open cell $\mathrm{Mg}$ alloy foam is rarely research. Due to the magnesium alloys have high reactivity with oxygen in the air ignition or combustion occurs rapidly when they are in contact with oxygen in the molten state. The mixing gas of $\mathrm{SF}_{6}$ and $\mathrm{CO}_{2}$ well solve the problem that magnesium alloy is easy to burn. Fluidity is one of the prime factors to be taken into account in foundry practices of open cell Mg alloy foam. The factors 
determining fluidity can be basically divided into metallurgical variables, such as composition, superheat, latent heat, surface tension, viscosity and solidification mode. ${ }^{20)}$

In this research, we used investment casting method. It was simple and low cost to cast. The molten AZ31 Mg alloys were cast onto the porous media, and the molten metal would infiltrate into the porous media under difference pressure with different temperatures. After solidification, metal/particle composite can be obtained. The open-cell Mg alloys foam has been fabricated successfully by removing the perform granules. The continued work being carried out on the various factors influence the fluidity of AZ31 Mg alloy foam.

\section{Experimental Procedure}

\subsection{Prepare Granular}

At first granules were made in rolling mixer machine by raw materials which are commercial salt (diameter $\leq 1$ $\mathrm{mm}$ ) as primary particle, plaster powder and perlite powder mixture, and used PVA (polyvinyl acetate) as binder during granule layer. The rolling mixer makes sure it has roundness and smooth surfaces, all of which are beneficial for the foam's properties. The granules were dried at the $100^{\circ} \mathrm{C}$ drying box, standard sieves (12 mesh, 8 mesh, 6 mesh) were used to divide into $1.70 \mathrm{~mm} \phi, 2.33$ $\mathrm{mm} \phi, 3.36 \mathrm{~mm} \phi$ as well as even size. So the $1.70 \mathrm{~mm}$ $\phi, 2.33 \mathrm{~mm} \phi$ and $3.36 \mathrm{~mm} \phi$ pore sizes of open cell $\mathrm{Mg}$ alloy foam obtained by the different granules. Fig. 1. shown micrographs of the typical morphologies of granule raw materials and $3.36 \mathrm{~mm} \phi$ size granule. The $3.36 \mathrm{~mm}$ $\phi$ granules can withstand the high casting temperature, infiltration pressure and easily removed by running water or blasting air. ${ }^{21)}$

\subsection{Fabricate open cell AZ31 Mg alloy foam}

Schematic diagram of apparatus for making the opencell $\mathrm{Mg}$ alloy foam are shown in Fig. 2. The foams were produced by the infiltrating process, and the preparation procedures of open-cell $\mathrm{Mg}$ alloy foam are: (1) A definite quantity of AZ31 Mg alloy was melted in a steel crucible in the upper furnace. (2) Prepared the porous leachable
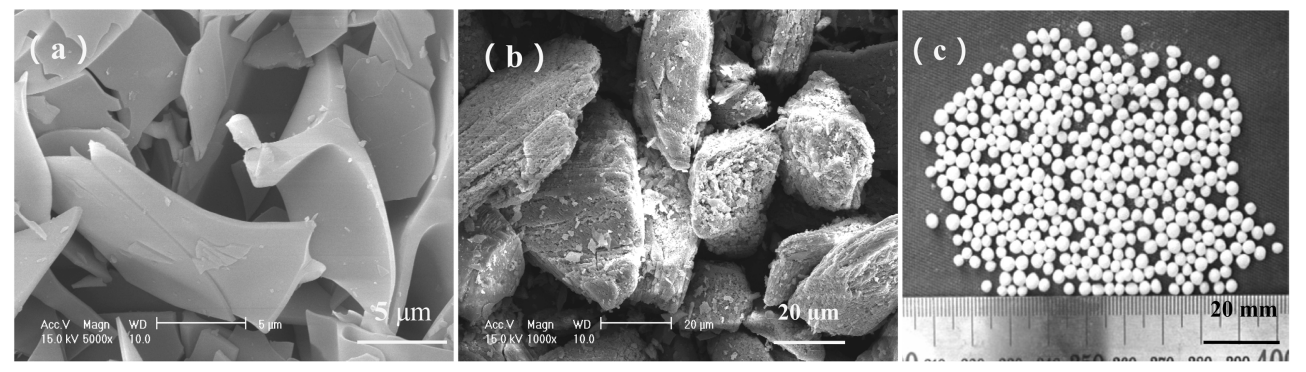

Fig. 1. SEM micrographs of granule morphologies of raw materials. (a) Perlite powder, (b) Plaster powder and (c) The granule size is $3.36 \mathrm{~mm} \phi$.

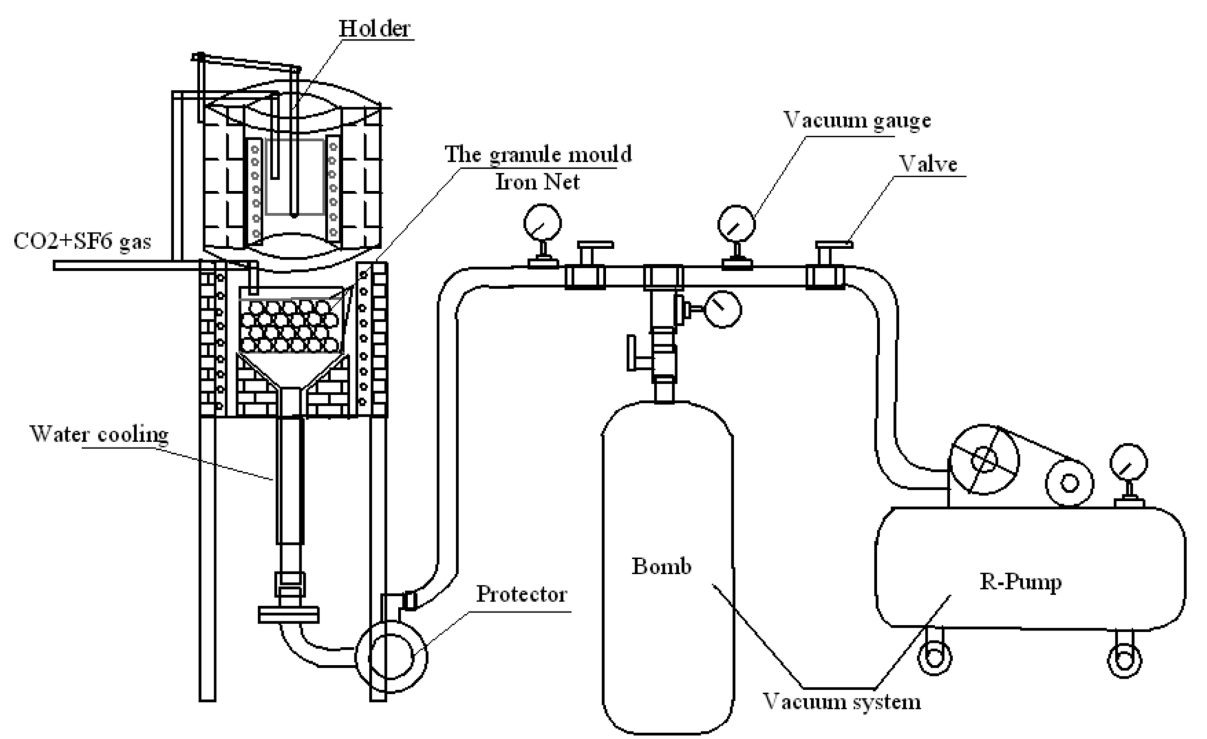

Fig. 2. Schematic diagram of apparatus for making open cell Mg alloy foams, as improved equipment, the advantages is provide adjustable vacuum pressure from the vacuum system. 
bead performs. Some same sizes of granule was arrangement in the granule mold. The pores shape is predominantly controlled by the initial shape of the space-holder granules that were used to producing the preforms. Pores of the resulting foam "replicate" the initial shape of these space-holder granules. (3) Infiltration of molten metal into the porous performs. (4) Solidification of the molten metal, metal/granules composite can be obtained. (5) Dissolution of the performs in a hot water, The open-cell $\mathrm{Mg}$ alloys foam has been fabricated successfully by removing the preform granules. The whole fabrication process is operated under the mixed gas atmosphere of $\mathrm{CO}_{2}$ and $\mathrm{SF}_{6}$ (volume ratio: 6:1) to prevent the melt from ignition. ${ }^{22}$

\section{3 the fluidity of open cell $\mathrm{Mg}$ alloy foam}

The red area represents molten AZ31 magnesium alloy. The white spheres represent the porous granule mold. The open cell $\mathrm{Mg}$ alloy foams were produced by the infiltrating process. In this process, pressure difference and temperature are very important parameters, and greatly influence open cell structure formation. The molten AZ31 alloy infiltrated length changes in granule mould that take place as the infiltration time of the composite material increased in Fig A, B, C and so on, corresponding to increased volume of the open cell $\mathrm{Mg}$ alloy after solidification process. The filling sequence are (A) filled $0 \%$, (B) filled $12.5 \%$, (C) filled $25 \%$, (D) filled $37.5 \%$, (E) filled $50 \%$, (F) filled $62.5 \%$, (G) filled $75 \%$, $(\mathrm{H})$ filled $87.5 \%$ and (I) filled $100 \%$ as Fig. 3. shown.

\subsubsection{Infiltration pressure analysis}

It may be stated in several different forms depending on the flow conditions. The more widely used macroscopical approach relies on the work from Darcy ${ }^{23)}$ who described the permeability of sand columns to a water
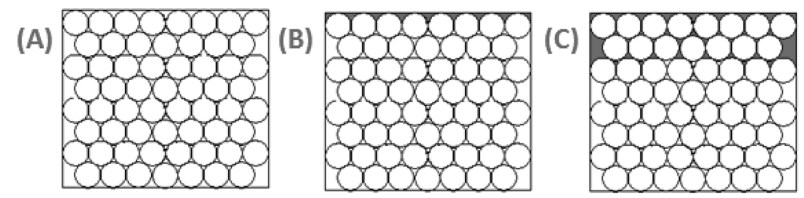

(D)
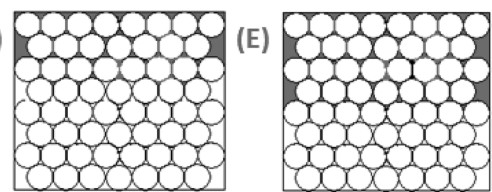

(G)
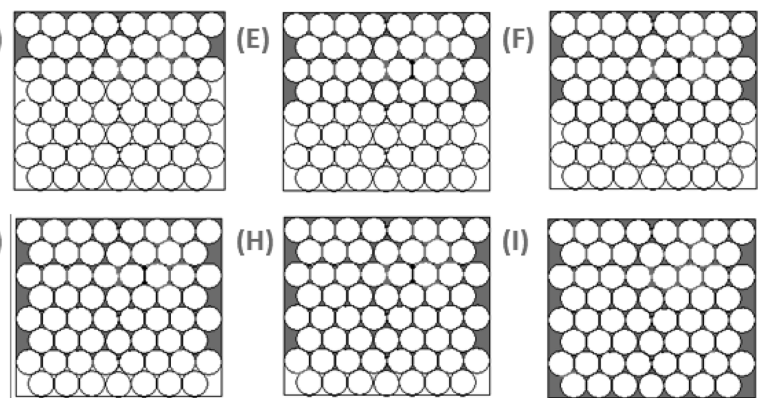

(I)

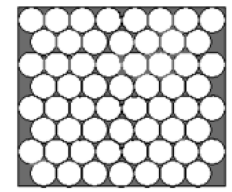

Fig. 3. Using this simple photos, we reappear the turbulent flow process with influence of infiltration pressure, preheat temperature on the infiltration distance of open cell $\mathrm{Mg}$ alloy. flow. This first gradient law writes

$$
Q=\kappa \frac{A}{\eta} \frac{\Delta \hat{P}}{\Delta L}
$$

Where $Q$ is the fluid flux $\left(\mathrm{m}^{3} \mathrm{~s}^{-1}\right), \Delta \hat{P}$ is the pressure (hydraulic head) differential in the flow (Pa), $\Delta L$ is the flow length (m), $\eta$ is the fluid dynamical viscosity $(\mathrm{Pa} \cdot \mathrm{s})$, $A$ is the area normal to the flow $\left(\mathrm{m}^{2}\right)$, and $k$ is the porous medium permeability $\left(\mathrm{m}^{2}\right)$. It shows the volumetric flow rate is a function of the flow area, elevation, fluid pressure and proportionality constant. ${ }^{24)}$

\subsubsection{Preheat temperature of mould analysis}

The infiltration process related to the fluidity, crystalline solidification and thermal exchange of magnesium liquid through the granule mould. Therefore, Preheat temperature was controlled in order to reduce the thermal exchange of the magnesium liquid with porous granules preform, metal molds, as well as the environment. This way is to extend the solidification time of magnesium liquid, increasing the fluidity of magnesium liquid. The fluidity time $\mathrm{t}_{0}$ is determined from M. X. Xu. ${ }^{24)}$

$$
t_{0}=\mathrm{T}_{\mathrm{E}}-\Psi \frac{V_{M} D_{M} \cdot H_{M}}{\mathrm{~V}_{\mathrm{P}} \mathrm{D}_{\mathrm{P}} \mathrm{C}_{\mathrm{P}}} \times\left(1-L_{M}\right)
$$

Where $\mathrm{t}_{0}$ is the preheat temperature of mould, $V_{m}$ is metal and granule composites of volume $\left(\mathrm{M}^{3}\right), \Psi$ is the size and shape coefficient of granule, $\Psi$ is fixed by actually experiment, $\Psi<1$. The granule size is smaller, the $\Psi$ is smaller. $T_{E}$ is the solidification temperature of the magnesium alloy $\left({ }^{\circ} \mathrm{C}\right) . C_{p}$ is Specific heat $\left(\mathrm{K}_{\mathrm{cal}} / \mathrm{Kg}^{*{ }^{\circ} \mathrm{C}}\right)$, $V p$ is the granule volume percent in composite material (\%). $H_{m}$ is Latent heat solidification of magnesium liquid $(\mathrm{J} / \mathrm{mol}) . D_{m}$ is the density of magnesium $\left(\mathrm{Kg} / \mathrm{M}^{3}\right) . D_{P}$ is the density of granule $\left(\mathrm{Kg} / \mathrm{M}^{3}\right) . L_{m}$ is the liquid fraction of liquid magnesium in composite. For theoretical analysis, there are certain guiding significance. In actual preparation we need to take care more the actual situation. ${ }^{24)}$ Such as ambient temperature, pore size and shape, and many other factors will influence on the infiltration length of magnesium alloy. In this paper, The room temperature is $20^{\circ} \mathrm{C}$, the preparation of granule size is $3.36 \mathrm{~mm} \phi$ for casting the open cell magnesium alloy foam, the preheating temperature of granule and mold is at $200^{\circ} \mathrm{C} \sim 500^{\circ} \mathrm{C}$.

\section{Results and Discussion}

We taked a certain amount of granules $(19.5 \mathrm{mg})$ to do the thermal gravity analysis test in air flow with a heating rate of $20 \mathrm{~K} / \mathrm{min}$ to analyze the granule thermal property. And the result is shown Fig. 4. The mass loss percentage at preheating temperature of $500^{\circ} \mathrm{C}$ was under 1.75 w.t \%, 


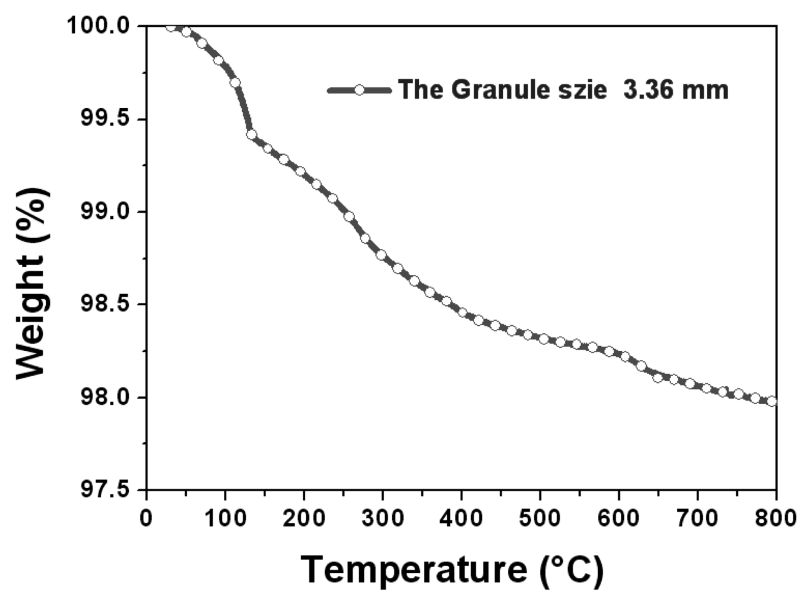

Fig. 4. TG analysis of granules.

so the preform granules are stable at this temperature.

In these experiments, the metal bottom is defined as the start, after the pouring $\mathrm{Mg}$ alloy, infiltration flow, and solidification. The filling capacity of fixed mould was evaluated by measuring the maximum height of the casting after solidification, We measured the infiltration length from bottom to top twelve times, removed from the average of the maximum and minimum average, We got the average distance and error value. Fig. 5 shows the macrostructures of the open cell AZ31 Mg alloy foams. The preheat temperature of mould and the infiltration pressure affect the infiltration length of open cell $\mathrm{Mg}$ alloy. The open cell AZ31 alloy fabricated by the preheat temperature of mould $\left(200^{\circ} \mathrm{C}, 300^{\circ} \mathrm{C}, 400^{\circ} \mathrm{C}\right.$, $500^{\circ} \mathrm{C}$ ), infiltration pressure at $3000 \mathrm{~Pa}, 4000 \mathrm{~Pa}, 5000$ $\mathrm{Pa}, 6000 \mathrm{~Pa}$. from the pictures, we know the infiltration length increased with infiltration pressure.

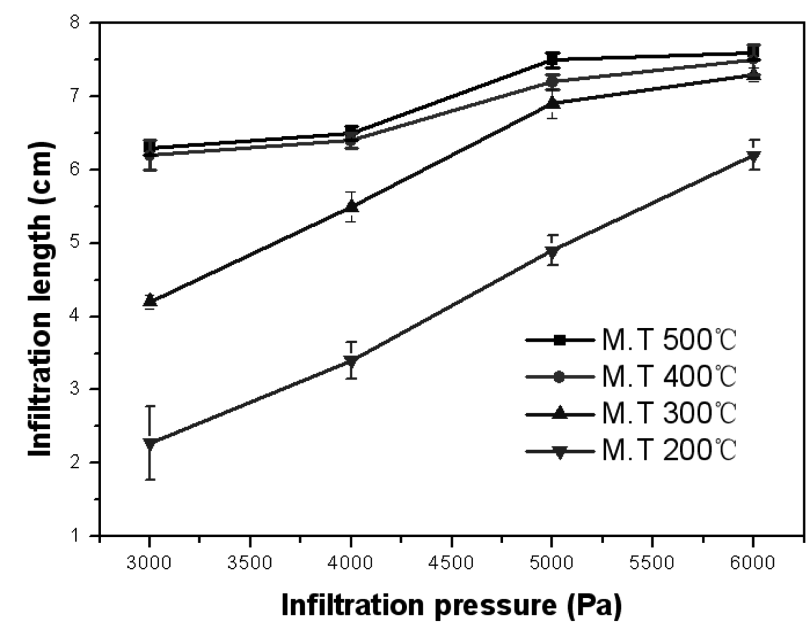

Fig. 6. The relationship between pressure and infiltration length at mould temperature $500^{\circ} \mathrm{C}, 400^{\circ} \mathrm{C}, 300^{\circ} \mathrm{C}$ and $200^{\circ} \mathrm{C}$. Melting temperature $750^{\circ} \mathrm{C}$, granule size $=3.36 \mathrm{~mm} \phi$.

Fig. 6. shows the relationship between the infiltration length and the infiltration pressure. A range of pressures affect the length of seepage for the open cell foam $\mathrm{Mg}$ alloy. In casting process, too low seepage pressure is not enough to fill the porous preforms, too high infiltration pressure will crush the granules or can be not formed integrally and uniform, affecting the quality of the open cell foam magnesium as well as increasing the threat level of the operating process. The molten $\mathrm{Mg}$ alloy can be infiltrated into the $3.36 \mathrm{~mm} \phi$ granule mould at least $3000 \mathrm{~Pa}$. The infiltration length increases with infiltration pressure increasing. However the infiltration length increases slowly over $5000 \mathrm{~Pa}$ vacuum pressure. The approximately $6000 \mathrm{~Pa}$ infiltration pressure for the granule

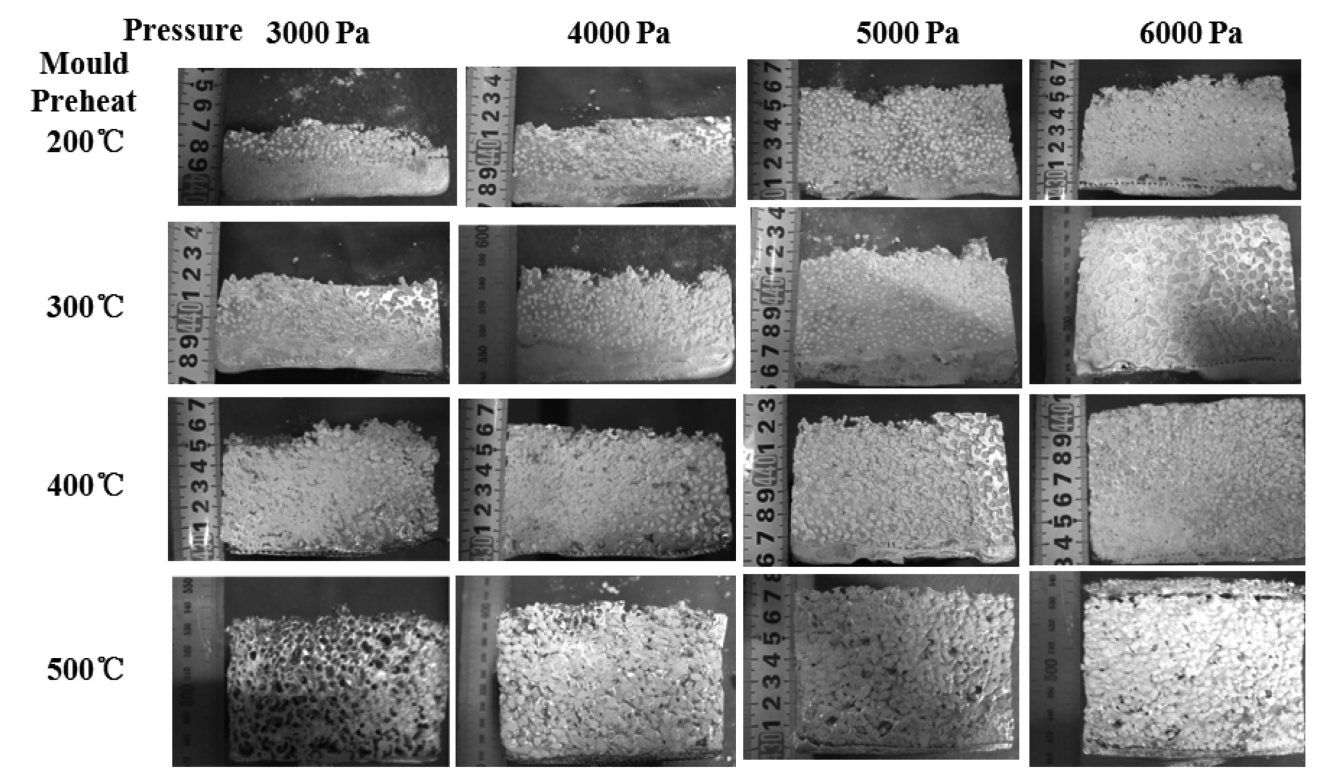

Fig. 5. The infiltration length of open cell sample used $3.36 \mathrm{~mm} \phi$ granule at various conditions. 


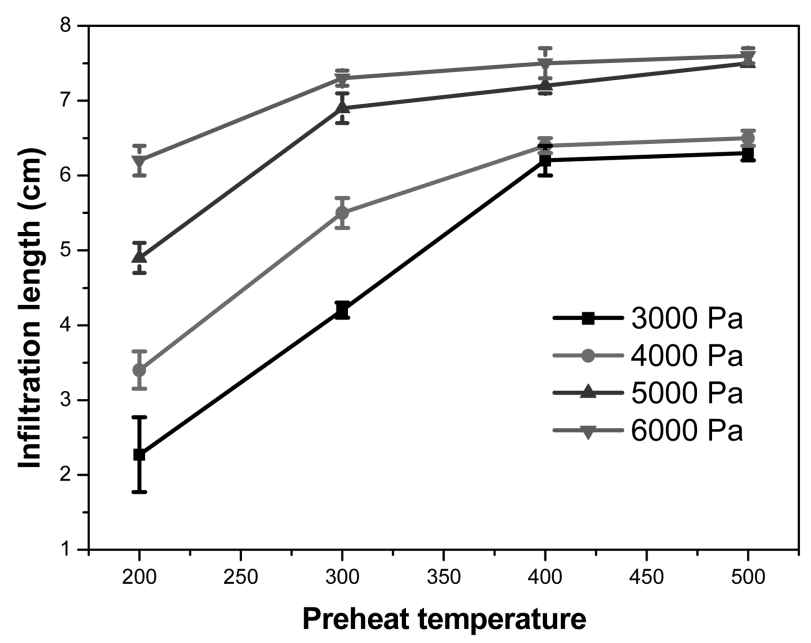

Fig. 7. The relationship between preheat temperature and infiltration length at gauge pressure $3000 \mathrm{~Pa}, 4000 \mathrm{~Pa}, 5000 \mathrm{~Pa}$ and $6000 \mathrm{~Pa}$. Melting $750^{\circ} \mathrm{C}$, Granule size $=3.36 \mathrm{~mm} \phi$.

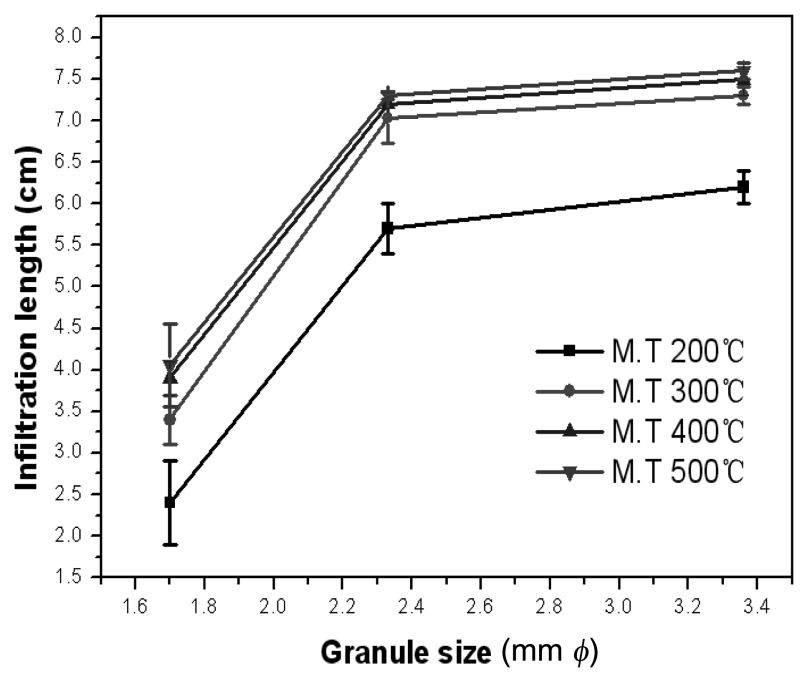

Fig. 8. The relationship between granule sizes and infiltration length at gauge pressure $6000 \mathrm{~Pa}$, melting temperature $750^{\circ} \mathrm{C}$, preheat temperature $200^{\circ} \mathrm{C}, 300^{\circ} \mathrm{C}, 400^{\circ} \mathrm{C}, 500^{\circ} \mathrm{C}$.

mould could be filled as deemed suitable.

The preheating temperature of the porous preforms has a significant impact on infiltration length. As the Fig. 7 shown, the seepage of magnesium liquid through the preforms can be divided into three processes: First, the existence of superheating degree is in the infiltration process; Second, after the disappearance of superheat the magnesium liquid starts to the solidification process. Due to the latent heat of solidification of the liquid magnesium, the semi-solid magnesium keeps flow until the solidified layer reaches a certain thickness, Seepage paths are blocked, the liquid magnesium seepage length ceases to increase.

Fig. 8. shows the relationship between the infiltration

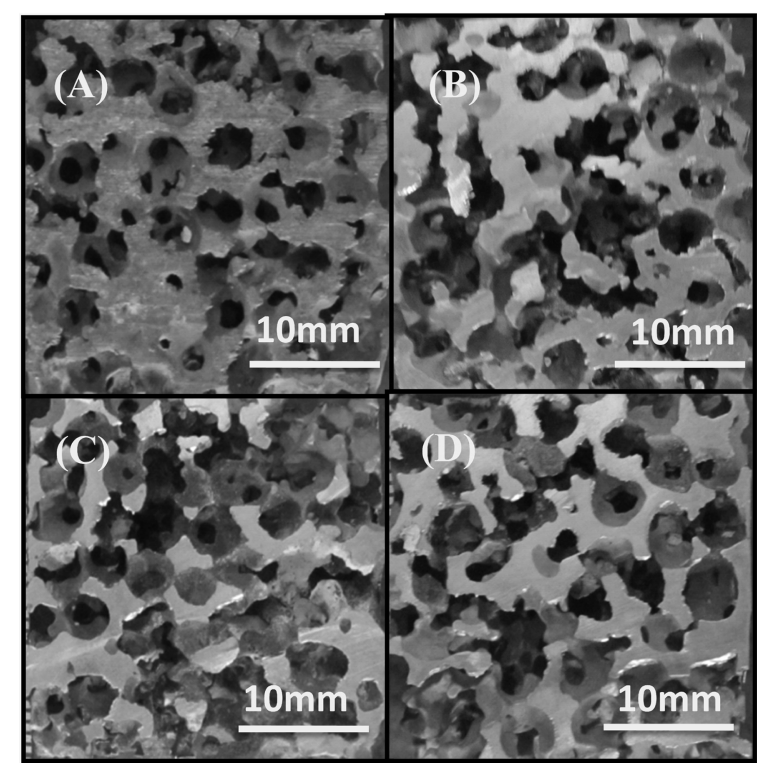

Fig. 9. The macrostructure AZ31 Mg alloy open cell foam used the vacuum system to obtain the different style control structure at melting $750^{\circ} \mathrm{C}$, preheat $400^{\circ} \mathrm{C}$.

length and the granule size, the infiltration length quickly reduce with decreasing the granule size at infiltration pressure $6000 \mathrm{~Pa}$, melting temperature $750^{\circ} \mathrm{C}$, preheat temperature $200^{\circ} \mathrm{C}, 300^{\circ} \mathrm{C}, 400^{\circ} \mathrm{C}, 500^{\circ} \mathrm{C}$. The smaller granule bring the higher requirement for the production equipment.

The optical macrographs, distribution and normal distribution of cross-sections through $3.36 \mathrm{~mm} \phi$ granule made by infiltrated process at melting temperature $750^{\circ} \mathrm{C}$, preheat $400^{\circ} \mathrm{C}$ in Fig. 9 and Fig. 10. As seen, there are slight differences in the cross-sections of the pore diameter. The peak of curve show the maximum number of pores in the cross-sections. The morphology of granule directly determines the pore macrostructure.

For (A), the maximum number of pore sizes are at 1.7 $\mathrm{mm} \phi$ to $1.9 \mathrm{~mm} \phi$, the peak of normal distribution described at $2.1 \mathrm{~mm} \phi$. For (B), The normal distribution is considered the same probability distribution in peak value. As (C), (D) shown, The normal distribution is approximation to describe the pore diameter distribution. But For (D), Its distribution is homogeneous than (C). There are several reasons for this: the normal distribution arises from the central limit theorem, It is suitable to applied in statistics. However, some cell wall and pore appeared some defects during removed granules process and casting process which made the normal distribution a little error.

The compressive stress-stain curves of open cell AZ31 $\mathrm{Mg}$ alloy foam with three kind of pore size are shown in Fig. 11. In all cases, the stress-strain curves of open cell $\mathrm{Mg}$ foams consist of three regions: an initial, approximately linear deformation region until the peak stress 

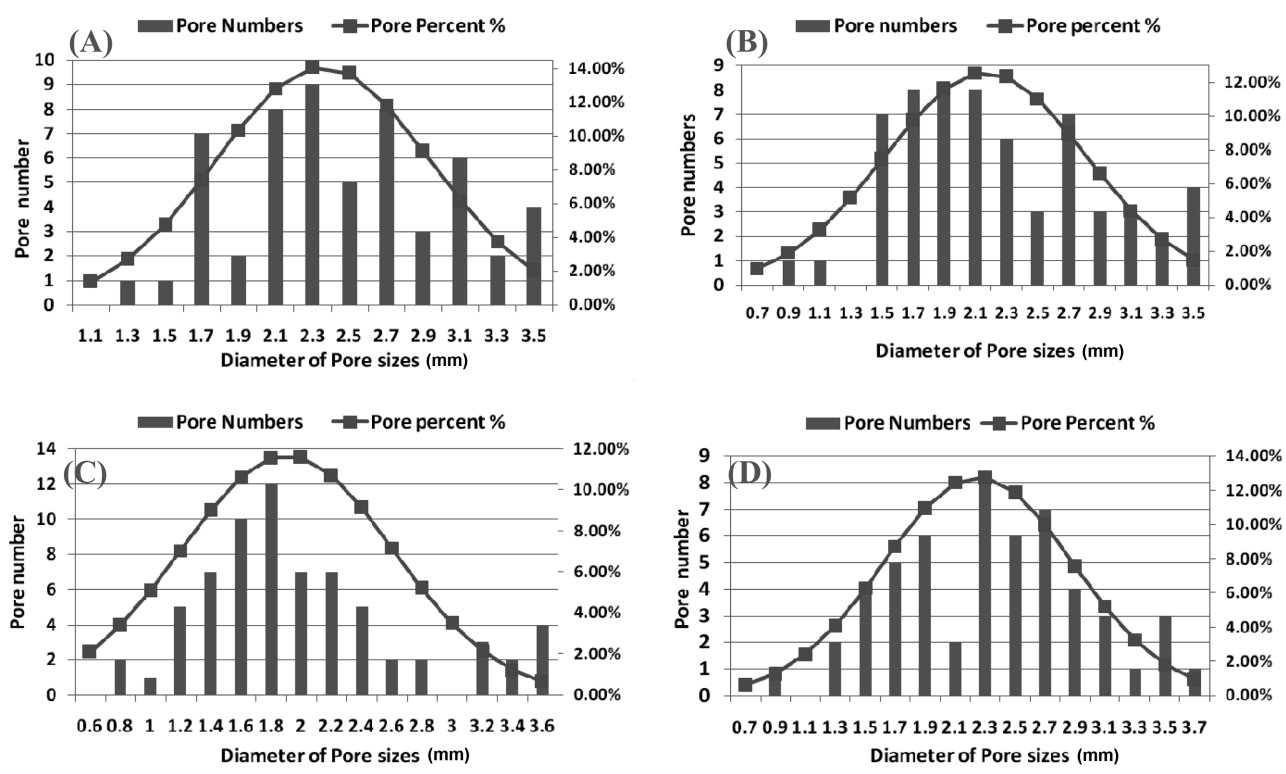

Fig. 10. The distribution and normal distribution fit of average pore size and pore percent for open cell foams by granule size $3.36 \mathrm{~mm} \phi$.

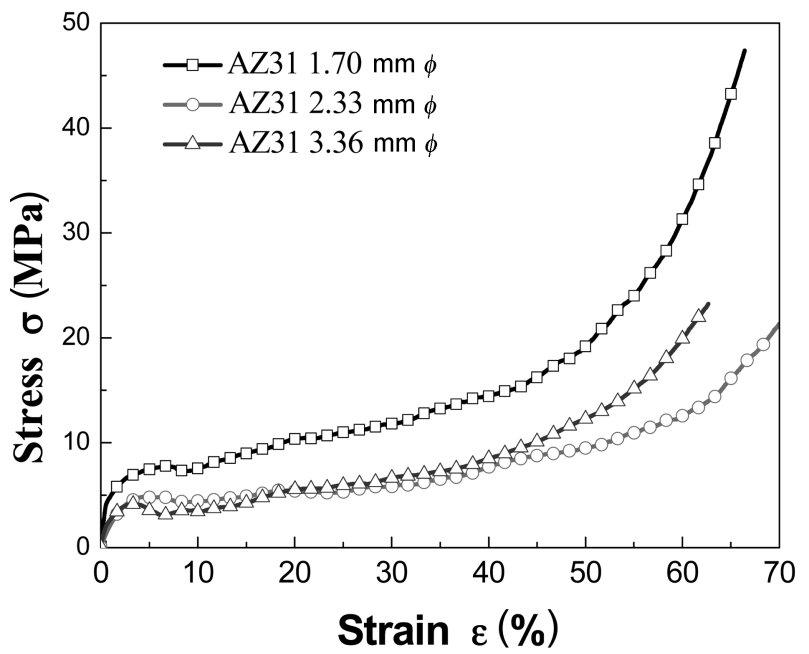

Fig. 11. Compressive stress-strain curves of AZ31 open cell $\mathrm{Mg}$ alloy foam.

followed by a stress drop to a plateau region, where the flow stress continuously drops to a plateau region, where the flow stress continuously drops with multiple serrations, indicative of a series of brittle cell edge fracture events and finally a densification region, in which the stress increases steeply due to the collapsed cells having been almost fully compacted together. ${ }^{25)}$

As shown in Fig. 12, the ideality energy absorption efficiency curves exhibits three stages: (I) fast rising stage, (II) sustained stage (starting from the high efficiency point) and (III) attenuating stage (starting from the attenuating point). The size $=3.36 \mathrm{~mm} \phi$ specimens reach to the high efficiency point quicker than the other two under the present experiment conditions. The size $=2.33$

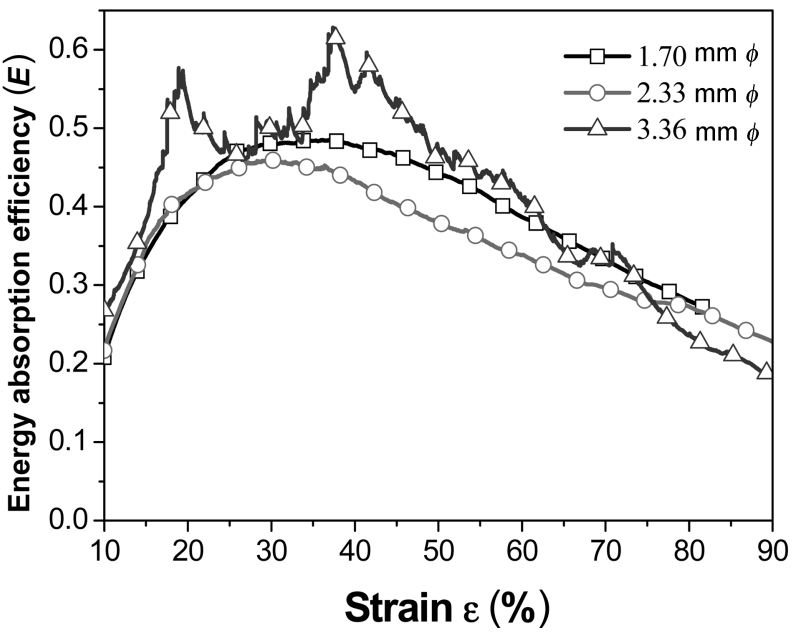

Fig. 12. Energy absorption efficiency and strain curve for the AZ31 open cell $\mathrm{Mg}$ alloy foam.

$\mathrm{mm} \phi$ and $1.70 \mathrm{~mm} \phi$ specimens curve in the sustained stage is much smoother than the size $=3.36 \mathrm{~mm} \phi$ specimens, which means specimens with can maintain steady energy absorption efficiency for longer time. Due to the highest energy absorption efficiency of metallic foams is obtained when the plateau region is horizontal and does not produce the peaks. Consequently specimens with higher pore size are characterized by higher energy absorption efficiency under the present experiment.

\section{Conclusion}

Open cell AZ31 Mg alloy are fabricated with the method of controlling various infiltration pressure, the preheat tem- 
perature of granule mould. The castability and fluidity properties of open cell $\mathrm{Mg}$ alloy foam is investigated. The conclusions are as follows:

1) Fluidity of $\mathrm{Mg}$ alloys increased with increase in more permeability pressure in the fixed mold. Fluidity behavior of open cell $\mathrm{mg}$ alloys foam is similar to the $\mathrm{Mg}$ alloys. The infiltration length increased slowly over $5000 \mathrm{~Pa}$ vacuum pressure. The maximum values of fluidity occurred at approximately $6000 \mathrm{~Pa}$.

2) Higher fluidity of the open cell AZ31 mg alloys foam is commonly observed in the mould of higher preheat temperature where the solidification process takes place slowly. The preheat temperature of granule mould is $200^{\circ} \mathrm{C}, 300^{\circ} \mathrm{C}, 400^{\circ} \mathrm{C}$ and $500^{\circ} \mathrm{C}$, respectively. Experimental data shows seepage length increase with the preheat temperature increasing. But high preheating temperature is adverse on energy saving. The preheat temperature deemed suitable is $400^{\circ} \mathrm{C}$.

3) At the same conditions, infiltration length quickly reduce with decreasing the granule size. The smaller granule need more requirement of the production equipment.

4) Compression behavior of AZ31 open cell Mg alloy foam shows typical porous materials. As the average pore size increased from $1.70 \mathrm{~mm} \phi$ to $3.36 \mathrm{~mm} \phi$, the compressed strength reduce. However, It is interesting that the $3.36 \mathrm{~mm} \phi$ size specimens have high energy absorption efficiency.

\section{Acknowledgement}

This research was supported by the ministry of education and human resources development thought the i-Cube Center, Brain Korea 21 (BK21) program, the ERI of Gyeongsang National University, Basic Science Research Program through the National Research Foundation of Korea (NRF) funded by the Ministry of Education, Science and Technology (2011-0006156) and ReCAPT in Gyeongsang National University.

\section{References}

1. B. Y. Hur and X. Zhu, Mater. Sci. Forum, 439, 200 (2003).

2. B. Y. Hur, B. -K. Park, S. -Y. Kim and H. Bae, Mater. Sci. Forum, 486-487, 472 (2005).
3. S. Y. Kim, B. Y. Hur, C. K. Kwon, D. K. Ahn and S. H. Park, J. Kor. Inst. Met. \& Mater., 40(8), 910 (2002).

4. M. V. Twigg and J. T. Richardson, Ind. Eng. Chem. Res., 46, 4166 (2007).

5. D. Fino, G. Saracco and V. Specchia, Chem. Eng. Sci., 57, 4955 (2002).

6. K. Raiber, P. Hammerschmid and D. Janke, ISIJ Int., 35, 380 (1995).

7. L. Tadrist, M. Miscevic, O. Rahli and F. Topin, Exp. Therm. Fluid. Sci., 28, 193 (2004).

8. S. Langlois and F. Coeuret, J. Appl. Electrochem., 20, 749 (1990).

9. P. J. Elverum, J. L. Ellzey and D. Kovar, J. Mater. Sci., 40, 155 (2005).

10. P. D. Plessis, A. Montillet, J. Comiti and J. Legrand, Chem. Eng. Sci., 49, 3545 (1994).

11. K. Boomsma, D. Poulikakos and Y. Ventikos, Int. J. Heat Fluid Flow, 24, 825 (2003).

12. J. T. Richardson, Y. Peng and D. Remue, Appl. Catal. Gen., 204, 19 (2000).

13. L. Giani, G. Groppi and E. Tronconi, Ind. Eng. Chem. Res., 44, 4993 (2005).

14. S. J. Kim and D. Kim, J. Heat Tran., 123, 527 (2001).

15. R. Gil, A. Jinnapat and A. R. Kennedy, Compos. Appl. Sci. Manuf., 43, 880 (2012).

16. D. Carnelli, G. Pennati, T. Villa, L. Baglioni, B. Reimers and F. Migliavacca, Artif. Organs, 35, 74 (2011).

17. M. P. Fernandez, in Proceedings of the 6th International Conference on Porous Metals and Metallic Foams; MetFoam 2009 (Bratislava, Slovakia, September 2009), P32.

18. N. Q. Zhao, B. Jiang, X. W. Du, J. J. Li, C. S. Shi and W. X. Zhao, Mater. Lett., 60, 1665 (2006).

19. K. R. Ravi, R. M. Pillai, K. R. Amaranathan, B. C. Pai and M. Chakraborty, J. Alloy. Comp., 456, 201 (2008).

20. K. Benedy and C. Joseph, Light Met. Age, 63, 36 (2005).

21. D. P. Yao, Master Thesis(in English), p. 4, Gyeongsang National University, Korea (2007).

22. E. W. Andrews and L. J. Gibson, Scripta Mater., 44, 1005 (2001).

23. H. M. Sui, Master Thesis(in English), p. 9, Gyeongsang National University, Korea (2006).

24. M. X. Xu, Master Thesis(in Chinese), p. 60-65, Taiyuan University of Technology, China (2009).

25. D. -H. Yang, B. -Y. Hur and S. -R. Yang. J. Alloy. Comp., 461, 221 (2008). 